\title{
Scholarly networks on resilience, vulnerability and adaptation within the human dimensions of global environmental change
}

\author{
Marco A. Janssen ${ }^{\mathrm{a}, \mathrm{b}, \mathrm{c}, *}$, Michael L. Schoon ${ }^{\mathrm{c}, \mathrm{d}}$, Weimao Ke ${ }^{\mathrm{e}}$, Katy Börner ${ }^{\mathrm{e}}$ \\ ${ }^{a}$ School of Human Evolution and Social Change, Arizona State University, Box 872402, Tempe AZ 85287-2402, USA \\ ${ }^{\mathrm{b}}$ Department of Computer Science and Engineering, Arizona State University, USA \\ ${ }^{\mathrm{c}}$ Workshop in Political Theory and Policy Analysis, Indiana University, USA \\ ${ }^{\mathrm{d}}$ School of Public and Environmental Affairs, Indiana University, USA \\ ${ }^{\mathrm{e}}$ School of Library and Information Science, Indiana University, USA
}

Received 21 August 2005; received in revised form 15 February 2006; accepted 18 February 2006

\begin{abstract}
This paper presents the results of a bibliometric analysis of the knowledge domains resilience, vulnerability and adaptation within the research activities on human dimensions of global environmental change. We analyzed how 2286 publications between 1967 and 2005 are related in terms of co-authorship relations, and citation relations.

The number of publications in the three knowledge domains increased rapidly between 1995 and 2005. However, the resilience knowledge domain is only weakly connected with the other two domains in terms of co-authorships and citations. The resilience knowledge domain has a background in ecology and mathematics with a focus on theoretical models, while the vulnerability and adaptation knowledge domains have a background in geography and natural hazards research with a focus on case studies and climate change research. There is an increasing number of cross citations and papers classified in multiple knowledge domains. This seems to indicate an increasing integration of the different knowledge domains.
\end{abstract}

(C) 2006 Elsevier Ltd. All rights reserved.

Keywords: Knowledge domains; Co-authorship networks; Resilience; Vulnerability; Adaptation; Citations; Publications

\section{Introduction}

In recent years, the concepts ${ }^{1}$ of resilience, vulnerability and adaptation have increasingly been used in the research on the human dimensions of global environmental change (HDGEC). We are interested in identifying the structure and dynamics of major fields contributing to the particular concepts within the research on HDGEC. We intend to identify the most influential scholars, publications, and

\footnotetext{
*Corresponding author. School of Human Evolution and Social Change, Arizona State University, Box 872402, Tempe AZ 85287-2402, USA.

E-mail address: Marco.Janssen@asu.edu (M.A. Janssen).

${ }^{1}$ These concepts are defined as a cross-cutting theme of the International Human Dimensions Programme on Global Environmental Change (IHDP). These concepts can have different meanings to different scholars. For example, "ecological resilience", "engineering resilience" and "social resilience" are covered by "resilience" (Holling, 1996; Adger, 2000).
}

journals in the knowledge domains resilience, vulnerability and adaptation. We wondered whether the knowledge domains were mainly acting independently, whether there was much cross fertilization, and how this has changed over time?

The study on HDGEC is performed by scholars from many different disciplines, including geography, political science, economics, ecology, environmental science, psychology, archaeology, mathematics, etc. In recent years, reviews have appeared on separate knowledge domains, such as by Gunderson (2000), Cutter (2003), and Smit et al. $(1999,2000)$. Four other papers in this special issue of Global Environmental Change discuss the theoretical and methodological developments of the concepts of resilience, vulnerability and adaptation with regard to HDGEC (Folke, 2006; Adger, 2006; Smit and Wandel, 2006), as well as their conceptual similarities and differences (Gallopin, 2006). 
The concept of resilience was introduced by Holling (1973) in the field of ecology. According to Holling (1973, p. 17) "resilience determines the persistence of relationships within a system and is a measure of the ability of these systems to absorb change of state variable, driving variables, and parameters, and still persist". Originally, resilience was used in the field of population ecology and in the study on managing ecosystems. As such, it is mathematically based and model oriented. Since the late 1980s, the concept has been used increasingly in the analysis of human-environmental interactions. A number of scholars working on the resilience of social-ecological systems have organized themselves since 1999, forming the Resilience Alliance.

The concept of vulnerability has its roots in the study on natural hazards. Vulnerability is defined as "the characteristics of a person or group in terms of their capacity to anticipate, cope with, resist, and recover from the impact of a natural hazard. It involves a combination of factors that determine the degree to which someone's life and livelihood is put at risk by a discrete and identifiable event in nature or in society"(Blaikie et al., 1994, p. 9). In the 1990s, natural hazards scholars started to focus on the vulnerability of people to impacts of environmental change, especially climate change. There is a disciplinary legacy of geography. In contrast to resilience, there has been little (Ionescu et al., 2006) focus on mathematical models, but more on the comparative analysis of case studies.

Adaptation of humans to environmental variability was a focus of anthropology since the early 1900s. In the 1990s, scholars began to use the term adaptation for the study on the consequences of human-induced climatic change, without explicitly relating this back to these conceptual origins in anthropology. The Intergovernmental Panel on Climate Change defines adaptation as "adjustment in ecological, social, or economic systems in response to actual or expected climatic stimuli and their effects or impacts. This term refers to changes in processes, practices, or structures to moderate or offset potential damages or to take advantage of opportunities associated with changes in climate. It involves adjustments to reduce the vulnerability of communities, regions, or activities to climatic change and variability" (McCarthy et al., 2001, p. 643).

A manual compilation and systematic review of all publications on resilience, vulnerability and adaptation seems to be impossible due to the large amount of papers and books published between 1960 and 2005 and the diversity of the scientific disciplines involved. Here we present a bibliometric analysis of the three knowledge domains by using tools and techniques developed for the large-scale mapping of knowledge domains (Börner et al., 2003; Shiffrin and Börner, 2004). This analysis requires the acquisition of a high-quality, comprehensive dataset of relevant papers, the analysis and correlation of these paper records, and the visualization of the results for means of communication. In particular, our goal is to objectively identify major research topics, experts, papers, etc., in the three knowledge domains of interest. In addition, we would like to identify interconnections of research outputs between the three knowledge domains.

The remainder of this paper presents the results of analyzing 2286 publications related to the study on resilience, vulnerability and adaptation as published between 1967 and 2005. These publications are mainly articles in international journal in English due to the way we collect our data. General statistics are provided; major journals, most productive authors and best connected authors are identified; and co-author and paper citation networks for the three areas as well as for the complete dataset are presented and discussed. Last but not least, we tried to answer if the different scientific communities interact and overlap more (leading to a merge of the fields) or less (due to an increasing flood of information and corresponding specialization) over time.

\section{Data collection}

Most research results in the domains of resilience, vulnerability and adaptation are published in journals. The Arts and Humanities Index, the Social Science Citation Index and the Science Citation Index as provided by the Institute of Scientific Information (ISI) were used to acquire raw material for the bibliometric analysis. A manual check of ISI's journal coverage confirmed that all relevant journals were covered.

The data were retrieved from ISI's Web of Science online interface (http://www.isiknowledge.com) between October 4 and 14, 2004. On the basis of expert feedback on a draft of this paper, additional data were downloaded between March 14 and 20, 2005. For each paper, information on the complete author, title, language, abstract, keywords, address, cited references, times cited, publisher information and subject category was saved. Two types of searches were performed: (1) a keyword-based search and (2) a cited reference search using seminal papers.

\subsection{Keyword-based search}

In collaboration with domain experts (see Acknowledgements), we created a set of keywords that cover major dimensions of research on global environmental change. The complete set of keywords used to retrieve papers on resilience, vulnerability and adaptation within the area of HDGEC is given in Table 1.

\subsection{Cited reference search}

A set of seminal papers, also called 'seeds', which are referred to frequently by scholars publishing on resilience, vulnerability and adaptations in HDGEC, was identified in consultation with various experts in the field (see Acknowledgements). These seeds include books, journal articles, and other types of papers and are given in Table 2. 
Table 1

Keyword combinations used to retrieve papers for the three knowledge domains

\begin{tabular}{|c|c|c|}
\hline Resilience & Vulnerability & Adaptation \\
\hline Resilience \& vulnerability & Vulnerability \& resilience & Adaptation \& resilience \\
\hline Resilience \& coral & Vulnerability \& coral & Adaptation \& coral \\
\hline Resilience \& eutrophication & Vulnerability \& eutrophication & Adaptation \& eutrophication \\
\hline Resilience \& desertification & Vulnerability \& desertification & Adaptation \& desertification \\
\hline Resilience \& climatic change & Vulnerability \& climatic change & Adaptation \& climatic change \\
\hline Resilience \& climate change & Vulnerability \& climate change & Adaptation \& climate change \\
\hline Resilience \& environmental change & Vulnerability \& environmental change & Adaptation \& environmental change \\
\hline Resilience \& land use change & Vulnerability \& land use change & Adaptation \& land use change \\
\hline Resilience \& food security & Vulnerability \& food security & Adaptation \& food security \\
\hline Ecological resilience & Ecological vulnerability & Adaptation \& human ecology \\
\hline & & Adaptive response \\
\hline & & Adaptive capacity \\
\hline & & Adaptive strategies \\
\hline & & Human biology ${ }^{\mathrm{a}}$ \\
\hline & & Adaptation \& environment ${ }^{\mathrm{a}}$ (only social science and humanity) \\
\hline & & Adaptability \& environment ${ }^{a}$ (only social science and humanity) \\
\hline
\end{tabular}

${ }^{\mathrm{a}}$ Added in the second round of information retrieval in March 2005.

Table 2

Seminal papers used to retrieve papers for the three knowledge domains based on cited reference search

\begin{tabular}{|c|c|c|}
\hline Resilience & Vulnerability & Adaptation \\
\hline Holling (1973) & White and Haas (1975) & Rappaport (1967) ${ }^{\mathrm{a}}$ \\
\hline May (1977) & Burton et al. (1978) & Rappaport (1977) \\
\hline Ludwig et al. (1978) & Sen (1981) & Butzer (1980) \\
\hline Timmerman (1981) & Timmerman (1981) & Timmerman (1981) \\
\hline Walker et al. (1981) & Clark (1985) & Rosenberg (1992) \\
\hline Pimm (1984) & Chambers (1989) & Easterling (1996) \\
\hline Holling (1986) & Swift (1989) & Smit et al. (1996) \\
\hline $\begin{array}{l}\text { Gunderson et al. } \\
\text { (1995) }\end{array}$ & Dow (1992) & Watson et al. (1996) \\
\hline $\begin{array}{l}\text { Berkes and Folke } \\
\text { (1998) }\end{array}$ & Liverman (1990) & $\begin{array}{l}\text { Smithers and Smit } \\
\text { (1997) }\end{array}$ \\
\hline Adger (2000) & Watts and Bohle (1993) & Smit et al. (1999) \\
\hline Scheffer et al. (2001) & Bohle et al. (1994) & Tol et al. (1998) \\
\hline $\begin{array}{l}\text { Gunderson and } \\
\text { Holling (2002) }\end{array}$ & Blaikie et al. (1994) & Smit et al. (2000) \\
\hline Berkes et al. (2003) & $\begin{array}{l}\text { Kasperson et al. (1995) } \\
\text { Cutter (1996) } \\
\text { Ribot et al. (1996) } \\
\text { Watson et al. (1996) } \\
\text { Hewitt (1997) } \\
\text { Watson et al. (1998) } \\
\text { Adger (1999) } \\
\text { Klein and Nicholls (1999) } \\
\text { McCarthy et al. (2001) } \\
\text { Kates et al. (2001) }\end{array}$ & McCarthy et al. (2001) \\
\hline
\end{tabular}

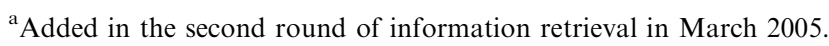

One seed is handled in a special way. The book by Sen (1981) is highly cited in various study areas related to poverty. Also within the study on vulnerability, it was used as a major source. Due to the large number (more than 400) of citations of Sen's (1981) book in the ISI database, of which many are not directly related to vulnerability, we decided to include only publications referring Sen (1981) when they also use the word "vulnerability" in the title, abstract or keywords.

\subsection{Data cleaning}

The title, keywords and abstract of each document that were retrieved by keyword-based and cited reference search were checked manually and independently by two experts, the first two authors of this article. Only publications in the area of human dimensions of environmental change were kept. Studies which focused exclusively on ecological dynamics (such as the resilience of plankton communities) or on social dynamics (such as the adaptation of organizations) were excluded. The decision to include or exclude a publication in the database was based on the information provided in the title and abstract of the publication. When in doubt, the publication was included. Only the 2286 papers relevant to the area of human dimensions of environmental change were kept. All data collection and manual cleaning was performed by the first 
two authors. For each knowledge domain, one researcher used seed documents and the other used keywords, so that many publications have been evaluated by two researchers independently to determine whether it needed to be included or not. Publications listed as book reviews were excluded.

Subsequently, all retrieved papers as well as the seeds were loaded onto an MS Access database for further data cleaning to eliminate duplicate records and unify different spellings of authors' names.

A number of very specific decisions were made. For example, the paper by Arrow et al. (1995) was published first in Science on April 28, 1995, and was reprinted in November 1995 in Ecological Economics and in February 1996 in Ecological Applications. We decided to keep only the Science paper and to count citations to the other versions as citations to the original Science paper. Other data cleaning details are provided on a supplementary webpage available online at http://www.public.asu.edu/ $\sim$ majansse/pubs/SupplementIHDP.htm

\subsection{Discussion of the dataset}

The acquired dataset has a number of potential shortcomings. It mostly covers journal papers, especially those published in English. Relevant books and book chapters might have been missed as they are not included in the ISI database. The non-English literature is largely excluded by using the ISI database. This might introduce bias for particular streams of research. A second issue is the coverage of the dataset. The concepts of resilience, vulnerability and adaptation have developed over time, and have been used in various ways, often unrelated to the study on HDGEC. Relevant papers that did not use the keywords given in Table 1 or did not cite the seeds listed in Table 2 were not retrieved.

In sum, while we aimed for the best and most complete set of relevant publications, we might have missed important contributions. Still, we believe we have a comprehensive dataset that covers the three areas well and can be used to analyze the structure and dynamics of research on resilience, vulnerability and adaptation within the area of HDGEC.

\section{Data analysis and visualization}

\subsection{General statistics}

The final dataset contains 2266 unique journal papers and 20 books and other non-journal publications published between 1967 and 2005. From those, 1084 report research on resilience, 939 are related to research in vulnerability, and 650 discuss research on adaptation. Some papers are classified into two or all three knowledge domains: 78 in adaptation and resilience, 258 in adaptation and vulnerability, 95 in resilience and vulnerability, and 44 in all three. In recent years, more papers seem to make

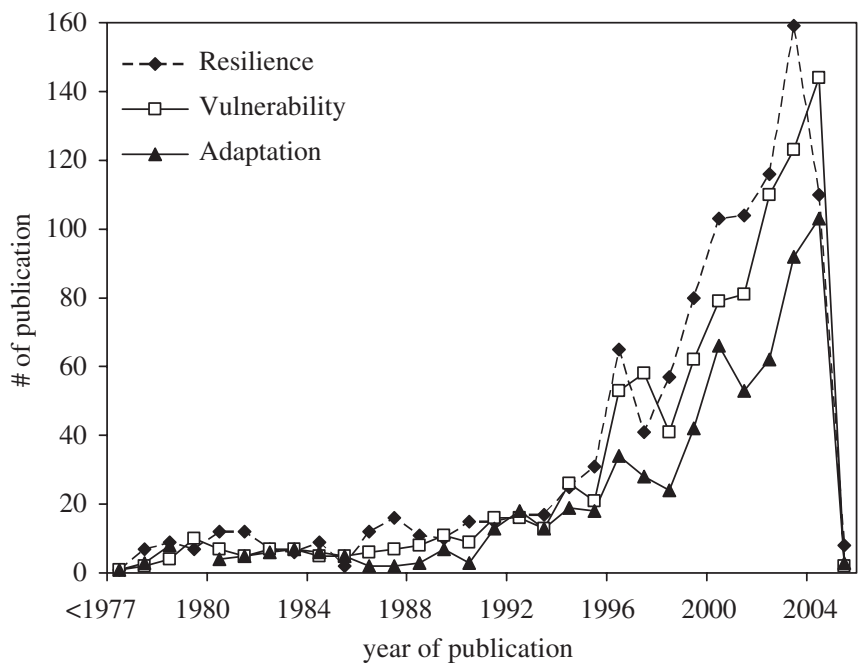

Fig. 1. Papers published in the three knowledge domains per year. Data for 2004 and 2005 are incomplete.

contributions to more than one knowledge domain, as we will discuss later.

Fig. 1 shows the number of papers in the three knowledge domains between 1977 and 2005. There appears to be a stable number of papers for all three areas till the early 1990s, after which the number of papers increases rapidly. This is surprising, as an analysis of all ISI data on papers shows a linear increase in papers over time (Boyack and Bäcker, 2004). This sharp increase in publications coincides with the increased interest in global environmental change, especially human-induced climatic change around the same time. Furthermore, during the 1990s, various institutions and networks started functioning, such as the International Human Dimensions Programme on Global Environmental Change (IHDP), Resilience Alliance, Sustainability Science group (organized in 2000-01), and Beijer International Institute of Ecological Economics (organized in 1991). Whether the creation of networks and institutions is responsible for the sharp increase in publications cannot be answered by the information available.

A closer examination of the dataset reveals that the number of authors per paper increased from 1.5 authors to 2.5 authors per paper between the 1970s and early 2000s. This might be a consequence of more collaboration, for example, via international interdisciplinary networks. This trend is similar for all three knowledge domains and is consistent with the trend in various disciplines (Guimerà et al., 2005).

\subsection{Journal statistics}

Which journals have published many articles in the various knowledge domains and which journals got most citations? When we exclude the 20 books and other nonjournal publications, we have 2266 papers, which have 
Table 3

Top 10 journals with the largest number of papers (left) and the highest number of citations (right) within the whole database, over the period 1977-2005

\begin{tabular}{|c|c|c|c|c|}
\hline & \multicolumn{2}{|c|}{ Papers published 1977-2005 } & \multicolumn{2}{|c|}{ Paper cited 1977-2005 } \\
\hline & Journal & $\begin{array}{l}\text { No. of } \\
\text { articles }\end{array}$ & Journal & $\begin{array}{l}\text { No. of citations } \\
\text { (no. of articles) }\end{array}$ \\
\hline 1 & Climatic Change & 96 & $\begin{array}{l}\text { Annual. Review of } \\
\text { Ecology }\end{array}$ & $400(8)$ \\
\hline 2 & $\begin{array}{l}\text { Global } \\
\text { Environmental } \\
\text { Change }\end{array}$ & 74 & Climatic Change & $334(96)$ \\
\hline 3 & Climate Research & 62 & Nature & $289(16)$ \\
\hline 4 & $\begin{array}{l}\text { Ecological } \\
\text { Economics }\end{array}$ & 58 & $\begin{array}{l}\text { Global } \\
\text { Environmental. } \\
\text { Change }\end{array}$ & $258(74)$ \\
\hline 5 & $\begin{array}{l}\text { Environmental } \\
\text { Management }\end{array}$ & 57 & Ecosystems & $199(29)$ \\
\hline 6 & Ambio & 50 & Science & $158(18)$ \\
\hline 7 & $\begin{array}{l}\text { Ecological } \\
\text { Applications }\end{array}$ & 34 & $\begin{array}{l}\text { Journal of Range } \\
\text { Management }\end{array}$ & $135(11)$ \\
\hline 8 & Human Ecology & 31 & $\begin{array}{l}\text { Ecological } \\
\text { Applications }\end{array}$ & $135(34)$ \\
\hline 9 & $\begin{array}{l}\text { Conservation } \\
\text { Ecology }\end{array}$ & 30 & Ambio & $123(50)$ \\
\hline 10 & $\begin{array}{l}\text { Ecosystems, } \\
\text { Environmental } \\
\text { Monitoring and } \\
\text { Assessment }\end{array}$ & 29 & $\begin{array}{l}\text { Progress in Human } \\
\text { Geography }\end{array}$ & $94(11)$ \\
\hline
\end{tabular}

been published in about 568 different journals. This shows a disperse nature of the research topics covered in this paper.

Table 3 (left) lists the top 10 journals in which most papers have been published. On top of the list are climatic change-oriented journals, followed by ecology and ecosystem management-oriented journals. Note that a number of these journals (e.g., Global Environmental Change, Conservation Ecology, ${ }^{2}$ Ecosystems) were created after 1990. If only publications from 2000 onwards are taken into consideration, the journals Climatic Change, Global Environmental Change, Ecological Economics, Conservation Ecology, Ambio and Environmental Monitoring and Assessment have published the most in these domains.

Table 3 (right) shows citation counts per journal, compiled using the HistCite ${ }^{\mathrm{TM} 3}$ software (Garfield, 2004). Note that these counts represent citations by and to publications within the set of 2266 papers. The most cited journal is the Annual Review of Ecology and Systematics; however, this ranking is primarily due to its publication of the most highly cited paper in this analysis-Holling (1973).

\footnotetext{
${ }^{2}$ Conservation Ecology was renamed Ecology and Society in 2004. However, Ecology and Society was not yet included in the ISI database at the time of data collection.

${ }^{3}$ We used Hist Cite version 2004.11.12.
}

Table 4 shows the top 10 journals that have the highest number of papers published in each of the three knowledge domains. Resilience-oriented papers are mainly published in ecology- and ecosystem management-oriented journals, which are quite different from the other two knowledge domains. The list of journals for papers on vulnerability shows that this concept has a background in geography (Annals of the American Association for Geography and natural hazard research (Disasters, Natural Hazards). The list of journals for papers on adaptation shows its roots in anthropology (American Anthropology, Human Ecology, Current Anthropology) and the current focus of climate and global change research on adaptation. Climate changeoriented journals are frequently used to disseminate research results in vulnerability and adaptation.

Using HistCite ${ }^{\mathrm{TM}}$, we ranked the journals according to their citation counts (analogous to Table 3) separately for each knowledge domain. Table 5 shows the dominance of ecology journals for the domain resilience, and geography and climate change for vulnerability and adaptation. We also see two journals on development studies in the domain of vulnerability (World Development, and the Institute for Development Studies (IDS) Bulletin).

\subsection{Author statistics}

Next, we were interested in identifying and analyzing the most productive and most collaborative authors within our database (including the 20 publications we excluded in the journal analysis). Some of the seeds in Table 2 are edited volumes, and for these publications only the editors have been included in the author statistics. Table 6 shows the top 10 authors who have the highest number of publications (left) and the highest number of citations (right) in our dataset. Professor Folke (Department of Systems Ecology at Stockholm University) leads with the highest number of publications. We used HistCite ${ }^{\mathrm{TM}}$ to calculate the number of times authors are cited. C.S. Holling, currently Emeritus Professor at the University of Florida, and previously at University of British Columbia (Canada) and the International Institute for Applied Systems Analysis (Austria), is by far the most cited author, followed by Folke.

Table 7 presents the most productive institutions and countries. Papers are allocated to institutions and countries on the basis of the affiliations of the first author. The most productive institution is Stockholm University, where Folke is Professor. Following institutions are Wisconsin University (Carpenter), CSIRO (Walker), University of East Anglia (Adger), UBC (Holling), and the University of Florida (Holling). The most productive countries (as measured by affiliation of first author) are USA, UK, and Canada. Since $97 \%$ of the papers are published in English, it is no surprise that the most productive countries are native English-speaking countries.

By using HistCite ${ }^{\mathrm{TM}}$, highly cited papers that are not part of our database were identified. These are Holling (1978) with 135 citations, Walters (1986) with 121, Ostrom 
Table 4

Top 10 journals with the largest number of papers in resilience, vulnerability and adaptation, over the period 1977-2005

\begin{tabular}{|c|c|c|c|c|c|c|}
\hline & \multicolumn{2}{|l|}{ Resilience } & \multicolumn{2}{|l|}{ Vulnerability } & \multicolumn{2}{|l|}{ Adaptation } \\
\hline 2 & Environmental Management. & 44 & Global Environmental Change & 52 & $\begin{array}{l}\text { Global Environmental } \\
\text { Change }\end{array}$ & 44 \\
\hline 3 & Ambio & 37 & Climate Research & 46 & Climate Research & 34 \\
\hline 4 & Ecological Applications & 31 & $\begin{array}{l}\text { Annals of the American } \\
\text { Association of Geographers }\end{array}$ & 23 & American Anthropology & 15 \\
\hline 5 & Conservation Ecology & 28 & Disasters & 23 & Human Ecology & 14 \\
\hline 6 & Ecosystems & 28 & Water, Air and Soil Pollution & 17 & $\begin{array}{l}\text { Environmental } \\
\text { Monitoring \& Assessment }\end{array}$ & 12 \\
\hline 7 & Ecological Modelling & 21 & Ambio & 16 & Climate Policy & 12 \\
\hline 8 & Conservation Biology & 16 & Environmental Monitoring \& Ass & 16 & Building Research & 9 \\
\hline 9 & Forest Ecology and Management & 16 & Ocean \& Coastal Management & 14 & Ecological Economics & 9 \\
\hline 10 & $\begin{array}{l}\text { Journal of Environmental } \\
\text { Management }\end{array}$ & 15 & Natural Hazards, Climate Policy & 13 & $\begin{array}{l}\text { IDS Bulletin, Current } \\
\text { Anthropology, Water Air } \\
\text { and Soil Pollution }\end{array}$ & 8 \\
\hline
\end{tabular}

Table 5

Top 10 journals with the largest number of citations in resilience, vulnerability and adaptation, over the period 1977-2005

\begin{tabular}{|c|c|c|c|c|c|c|}
\hline & \multicolumn{2}{|l|}{ Resilience } & \multicolumn{2}{|l|}{ Vulnerability } & \multicolumn{2}{|l|}{ Adaptation } \\
\hline & Journal & $\begin{array}{l}\text { No. of } \\
\text { received } \\
\text { papers }\end{array}$ & Journal & $\begin{array}{l}\text { No. of } \\
\text { received } \\
\text { papers }\end{array}$ & Journal & $\begin{array}{l}\text { No. of } \\
\text { received } \\
\text { papers }\end{array}$ \\
\hline 1 & Annual Review of Ecology & $398(8)$ & $\begin{array}{l}\text { Global Environmental } \\
\text { Change }\end{array}$ & $154(52)$ & Climatic Change & $189(57)$ \\
\hline 2 & Nature & $263(8)$ & Climatic Change & $152(61)$ & $\begin{array}{l}\text { Global Environmental } \\
\text { Change }\end{array}$ & $113(44)$ \\
\hline 3 & Ecosystems & $180(28)$ & $\begin{array}{l}\text { Progress in Human } \\
\text { Geography }\end{array}$ & $80(8)$ & Climatic Research & $28(34)$ \\
\hline 4 & $\begin{array}{l}\text { Journal of Range } \\
\text { Management }\end{array}$ & $130(11)$ & IDS Bulletin & $74(12)$ & $\begin{array}{l}\text { Agricultural and Forest } \\
\text { Meteorology }\end{array}$ & $24(5)$ \\
\hline 5 & Ecological Applications & $114(31)$ & Science & $53(6)$ & $\begin{array}{l}\text { Progress In Human } \\
\text { Geography }\end{array}$ & $19(4)$ \\
\hline 6 & Ambio & $94(37)$ & $\begin{array}{l}\text { Annals of the American } \\
\text { Association of Geographers }\end{array}$ & $50(23)$ & $\begin{array}{l}\text { Building Research \& } \\
\text { Info }\end{array}$ & $17(9)$ \\
\hline 7 & Science & $80(12)$ & Climate Research & $37(46)$ & $\begin{array}{l}\text { Professional } \\
\text { Geographer }\end{array}$ & $15(3)$ \\
\hline 8 & Journal of Ecology & $66(3)$ & World Development & $34(8)$ & Ambio & $14(7)$ \\
\hline 9 & Ecological Economics & $64(51)$ & Ambio & $25(16)$ & $\begin{array}{l}\text { Environmental } \\
\text { Monitoring \& } \\
\text { Assessment }\end{array}$ & $14(12)$ \\
\hline 10 & Conservation Biology & $62(16)$ & $\begin{array}{l}\text { Geoforum, Environmental } \\
\text { Monitoring \& Assessment, } \\
\text { Disasters }\end{array}$ & $23(8,16,23)$ & $\begin{array}{l}\text { Nature, American } \\
\text { Anthropology }\end{array}$ & $12(6,15)$ \\
\hline
\end{tabular}

The figures in parentheses are the number of articles in that journal in that knowledge domain.

(1990) with 110, Hardin (1968) with 77, Ludwig et al. (1993) with 73, Blaikie and Brookfield (1987) with 68, Vitousek et al. (1997) with 60, Costanza R d'Arge et al. (1997) with 55, Rosenzweig and Parry (1994) with 52 and Levin (1992) with 45 citations. The reason that they are not included is that some of them are not in the ISI Web of Knowledge (books, and papers before 1977) and were not used as seeds. Those who are in the ISI Web of Knowledge, and are not included in our database, did not refer to seed publications and/or use the keywords given above.

\subsection{Co-author networks}

Next, we were interested in understanding the scholarly interactions and the structure of the research community based on co-authorship relations. A total of 3860 unique 
Table 6

Top 10 authors of the complete dataset

\begin{tabular}{rllll}
\hline & \multicolumn{2}{l}{ Number of publications } & & \multicolumn{2}{l}{ Number of times cited } \\
\cline { 2 - 3 } \cline { 5 - 5 } Author & $\begin{array}{l}\text { No. of } \\
\text { publications }\end{array}$ & Author & $\begin{array}{l}\text { No. of } \\
\text { citations }\end{array}$ \\
\hline 1 & C. Folke & 50 & C.S. Holling & 1280 \\
2 & C.S. Holling & 23 & C. Folke & 481 \\
3 & S.R. Carpenter & 20 & L.H. Gunderson & 325 \\
4 & B.H. Walker & 19 & B.H. Walker & 307 \\
5 & F. Berkes & 17 & R.W. Kates & 229 \\
6 & C. Perrings & 16 & F. Berkes & 229 \\
7 & J.B. Smith & 15 & S.S. Light & 218 \\
8 & W.N. Adger & 14 & I. Burton & 188 \\
9 & R.W. Kates & 14 & G.F. White & 183 \\
10 & B.L. Turner & 14 & S.R. Carpenter & 183 \\
\hline
\end{tabular}

The left part of the table lists the authors with the most publications. The right part of the table shows the authors with the largest number of citations.

Table 7

Top 10 highly productive institutions (left) and countries (right)

\begin{tabular}{|c|c|c|c|c|}
\hline & \multicolumn{2}{|c|}{ Number of publications } & \multicolumn{2}{|c|}{ Number of publications } \\
\hline & Institution & $\begin{array}{l}\text { No. of } \\
\text { publications }\end{array}$ & Country & $\begin{array}{l}\text { No. of } \\
\text { publications }\end{array}$ \\
\hline 1 & $\begin{array}{l}\text { Stockholm } \\
\text { University }\end{array}$ & 69 & USA & 1045 \\
\hline 2 & $\begin{array}{l}\text { University of } \\
\text { Wisconsin }\end{array}$ & 60 & UK & 282 \\
\hline 3 & CSIRO & 58 & Canada & 272 \\
\hline 4 & $\begin{array}{l}\text { University of East } \\
\text { Anglia }\end{array}$ & 53 & Australia & 152 \\
\hline 5 & $\begin{array}{l}\text { University of } \\
\text { British Colombia }\end{array}$ & 51 & Netherlands & 116 \\
\hline 6 & $\begin{array}{l}\text { University of } \\
\text { Florida }\end{array}$ & 38 & Sweden & 112 \\
\hline 7 & $\begin{array}{l}\text { Wageningen } \\
\text { University }\end{array}$ & 38 & Germany & 69 \\
\hline 8 & $\begin{array}{l}\text { University of } \\
\text { Guelph }\end{array}$ & 35 & France & 62 \\
\hline 9 & $\begin{array}{l}\text { University of } \\
\text { Colorado }\end{array}$ & 33 & South Africa & 46 \\
\hline 10 & $\begin{array}{l}\text { Royal Swedish } \\
\text { Academy, US } \\
\text { EPA }\end{array}$ & 32 & India & 39 \\
\hline
\end{tabular}

The publications are distributed to the institutions and countries of the lead author. For 91 publications, this information was not available.

authors and 10,286 co-authorship relations were identified in the complete dataset. By representing authors as nodes and their co-authorship relations as edges, the links between nodes and co-author networks can be analyzed and visualized. This visualization is of interest, as it may help us to identify structures of collaboration between authors.

Different thresholds were applied to identify and map the most productive authors, the best connected authors and the strongest co-authorship relations. In particular, we identified all nine authors who had at least 50 unique coauthors. Next, we selected the 17 most productive authors with a minimum of 10 papers. Both sets make up the set of 22 authors who are very productive and/or collaborative. Next, we determined all co-authors for those 22 authors, but kept only those 67 authors who had a minimum of five papers. The thresholds were manually selected such that the number of authors and their co-authorships was sufficiently large to derive meaningful structures. We balanced the desire to provide a lot of data points, but not too many in order to be identifiable nodes. We acknowledge that this procedure is somewhat subjective, but small changes in the thresholds had no significant impact on the structure of the network, only the visual transparency.

The resulting network was laid out using the Pajek (Batagelj and Mrvar, 1997) network visualization package (Fig. 2). The most densely linked group of authors around the Folke node publishes in the domain of resilience. This densely linked group consists mainly of members of the Resilience Alliance (RA) and scholars affiliated with the Beijer International Institute of Ecological Economics. The other knowledge domains are more dispersed.

Next, we wanted to examine the correlation between international research networks and co-authorship networks. Although we cannot identify the precise causal relationships (was it the network that stimulated coauthorships or the other way around), it did provide us with some indication of the position of scholars of different networks in the knowledge domains. We analyzed the participation of authors in various international research networks, like IHDP, Intergovernmental Panel on Climatic Change (IPCC), Sustainability Science (SS) and RA. An author is defined to be participating when (s)he is listed as an author or reviewer in McCarthy et al. (2001), the http:// www.ihdp.uni-bonn.de/html/who/whoiswho.html (accessed on January 13, 2005), is a board member of the RA in 2004, or is listed in the research group on SS (see http:// sust.harvard.edu/people.htm; accessed on January 12, 2005).

Fig. 3 shows four networks that have the layout identical as shown in Fig. 2, but are color coded according to the author's participation in IHDP, IPCC, SS and RA. Author nodes are given in white when the author is not listed as an official member and are colored otherwise. The author with the most formal participations (three) in the international networks is William Clark, Harvard University and former graduate student of C.S. Holling.

We see that RA and SS, which are self-organized research networks, are clustered in a small area of the author network space. IPCC and IHDP cover a larger part of the whole co-author network, although we also see clusters in those networks. Future analysis of different dates of the co-authorship networks may illuminate whether the creation of international networks affected the structure of co-authorship networks. 


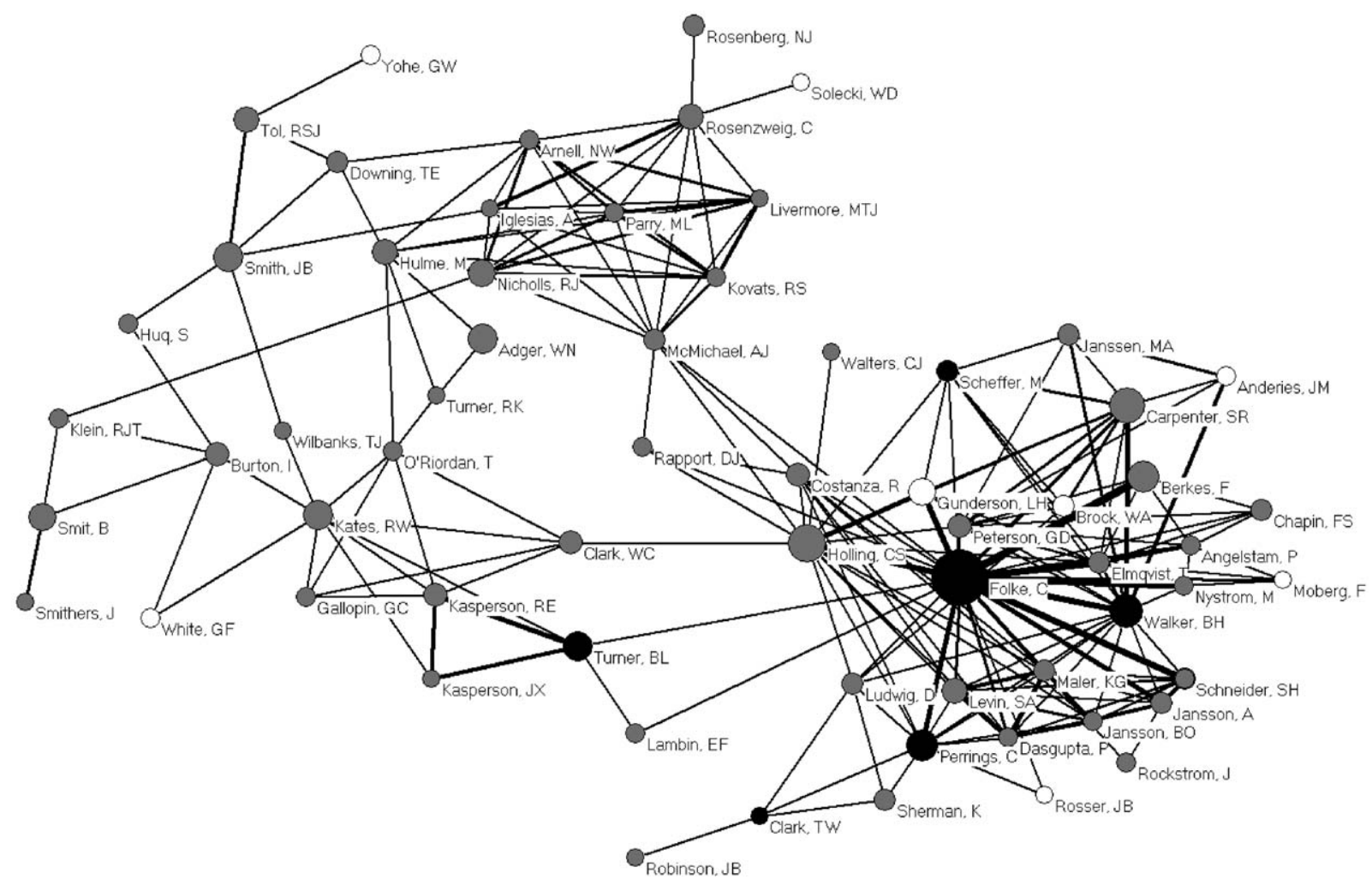

Fig. 2. Co-author network of most productive and best connected authors with the strongest co-authorship relations. Circles denote author nodes and are labeled by the authors' last name and first initials. The larger the node, the more publications. The darker the node, the more the co-authors. Black nodes refer to 50 or more co-authors, while white nodes refer to less than 10 co-authors. Edges represent co-authorship relations. The width of an edge represents the relative number of co-author relationships.

\subsection{Paper citation networks}

To analyze and communicate the paper-citation network, we imported the complete dataset (citations in the 20 publications that were not in the ISI database were entered manually) into Hist Cite ${ }^{\mathrm{TM}}$ (Garfield, 2004). The resulting graph for the complete dataset is given in Fig. 4. The graphs for each of the three domains are shown in Figs. 5-7. In all graphs, nodes represent highly cited papers and edges denote citation links. The nodes are sorted in time with older papers on the top and younger papers at the bottom.

Fig. 4 shows the papers that are cited at least 30 times within the whole database, and if one of these highly cited papers cites another highly cited paper, they are linked. The paper by Holling (1973) is the most cited (362 times). Papers from very different knowledge domains cite the paper by Holling (1973). Another major publication that is highly cited across disciplinary boundaries is by Burton et al. (1978). ${ }^{4}$ Interestingly, the knowledge domain resilience develops quite separately from the domains vulnerability and adaptation. Very few cross citations exist. Only Holling (1986) cited Burton et al. (1978), and a few

\footnotetext{
${ }^{4}$ We combined citations referring to the 1978 and 1993 editions.
}

"vulnerability/adaptation" papers and books refer to major resilience publications.

We also generated citation networks for the separate knowledge domains (Figs. 5-7). For the knowledge domain resilience, we used a threshold of 20 citations, and this figure is similar to the left part in Fig. 4. In the earlier years of this knowledge domain, we see papers on non-linear ecosystem properties (Holling, 1973; May, 1977; Pimm, 1984). Since the late 1970s, a number of key application areas developed. Among them are the management of forest for insect outbreaks (Ludwig et al., 1978), rangeland management (Walker et al., 1981; Westoby et al., 1989; Laycock, 1991; Friedel, 1991), and the management of lakes (Carpenter et al., 1999). Holling (1986) was instrumental in bringing the concept to the human dimensions of environmental change, leading to major papers on ecosystem management (Walters and Holling, 1990; Holling and Meffe, 1996). Gunderson et al. (1995), Berkes and Folke (1998), Gunderson and Holling (2002), and Berkes et al. (2003) have focused on comparing case studies on various regional social-ecological systems to understand how systems can deal with change and disturbances. The network of major papers shows the development of theoretical ecosystem properties to current applications on social-ecological systems. 

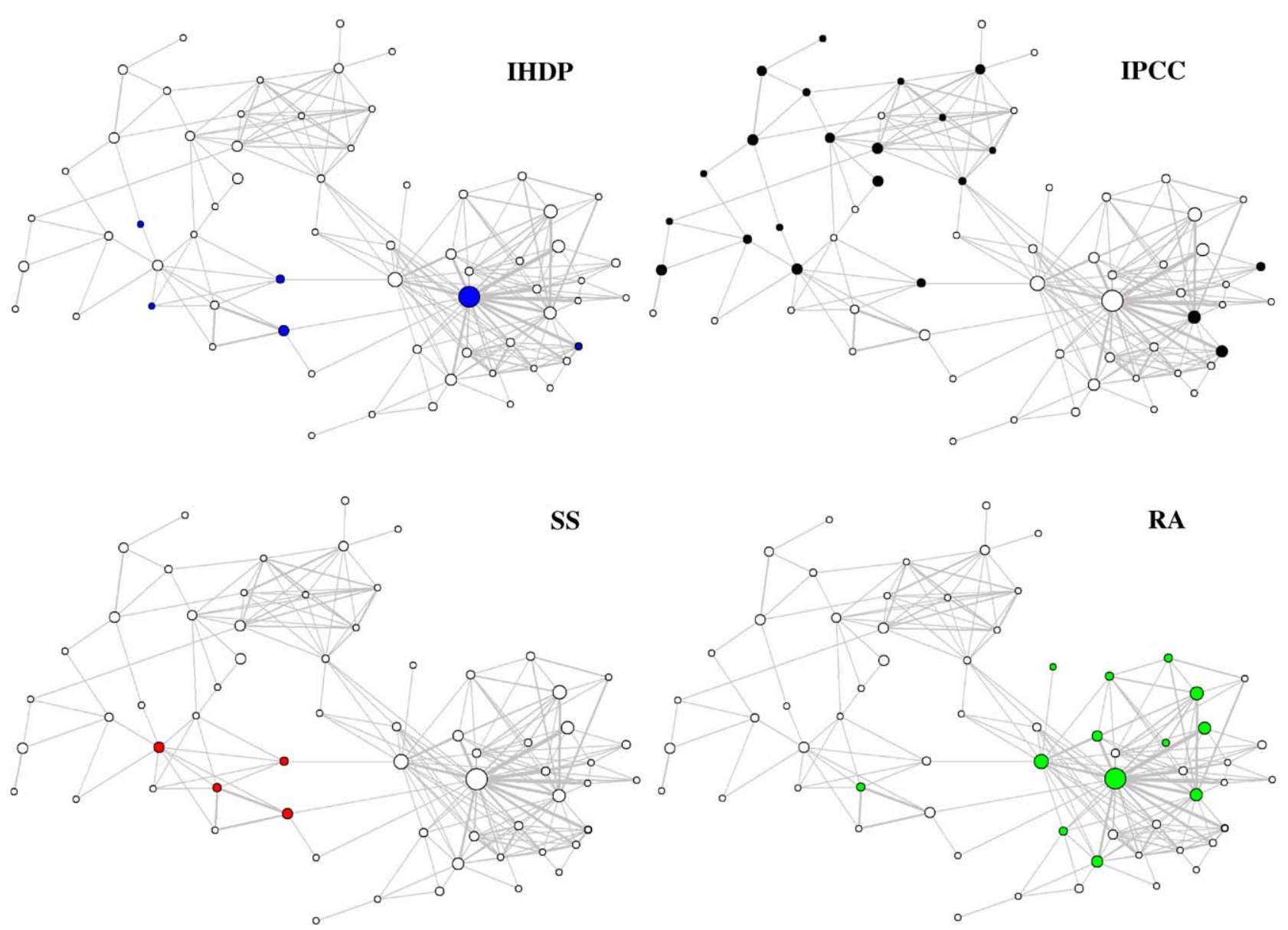

RA

Fig. 3. Participation of scholars in different international networks using the spatial lay-out of the co-authorship network given in Fig. 2. IHDP, International Human Dimensions Programme on Global Environmental Change; IPCC, Intergovernmental Panel on Climate Change; SS, Sustainability Network; and RA, Resilience Alliance.

The knowledge domain vulnerability mapped using a threshold of 15 citations shows the centrality of Burton et al.'s (1978) research on the environment as a natural hazard. Chambers (1989) and Swift (1989) used the term vulnerability, but mainly in relation to poverty and development. Liverman's (1990) work connected the term vulnerability to global environmental change. A conceptual framework for vulnerability was introduced by Blaikie et al. (1994). Vulnerability research was increasingly influenced by research on climate change, which explains citation of the IPCC reports (Watson et al., 1996, 1998; McCarthy et al. 2001). Kates et al.'s (2001) paper was on a recently formed network on sustainability science, which may affect the citation and co-authorship dynamics in this knowledge domain in the long run.

Rappaport (1967) was included as a seed for the adaptation knowledge domain, but it is not cited by other highly cited papers on adaptation The geographer Butzer (1980) wrote a remarkable paper on adaptation to global environmental change, where he connected the insights from anthropology to the emerging literature on global environmental change. This anthropological perspective is not directly connected with the dominant use of the term adaptation since the 1990s in the research on climate change. Since the 1990s, there is an increasing use of the term adaptation with regard to climatic change. Rosenberg (1992) published on adaptation of agriculture to climatic change. Most of the research on adaptation has focused on the agriculture sector, but since the late 1990s, the scope of sectors adapting to climate change was broadened, whereas remaining was climate change oriented (Smithers and Smit, 1997; Tol et al., 1998).

An early synthesis of the concepts of resilience, vulnerability, and adaptation was made by Timmerman (1981), but this paper is not found to be a highly cited paper within the whole database. It is not cited among the highly cited papers on resilience. However, it is cited within the knowledge domains vulnerability and adaptation. Interestingly, it cites Rappaport (1977).

Next, we analyzed the complete paper citation networks to analyze if there is a general trend for papers to fall into multiple knowledge domains. By complete, we mean all the citations of papers in the database linked to any other paper in the database. The results are given in Fig. 8. 


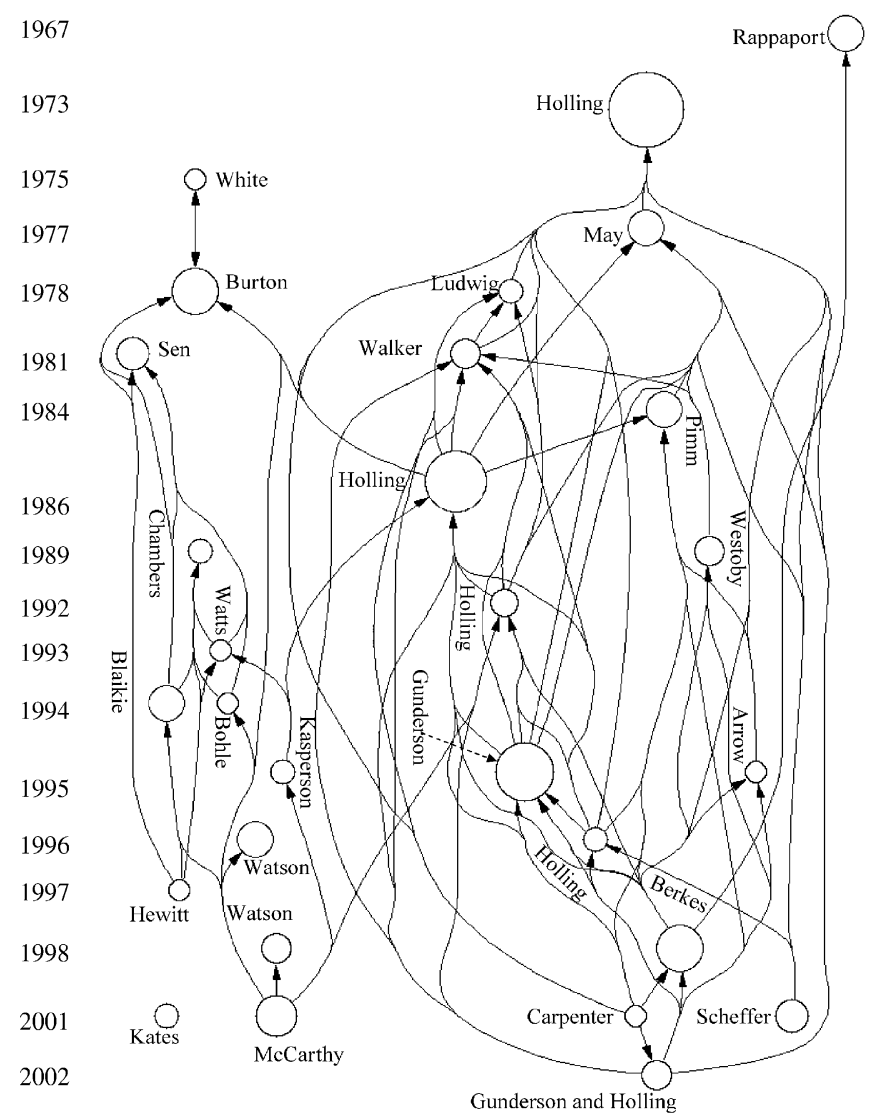

Fig. 4. Paper citation network of the most highly cited papers within the whole dataset (threshold 30 citations within the dataset). The node size denotes the number of citations, the arrows refer to citations (Carpenter et al., 2001; Holling, 1992).

About $20 \%$ of the papers published in the last five years can be categorized into two or three knowledge domains. One of the reasons for the increasing overlap might be the more complete coverage of abstracts in the ISI database since 1995. It appears that scholars more frequently use keywords from different knowledge domains or cite seminal papers from various knowledge domains. In sum, we are not able to provide a univocal explanation for the increased overlap.

When we analyze the cross citations between papers that are not members of the same knowledge domain, and relate this to the expected number of cross citations when papers would randomly cite other papers in this database, we see an increase of relative cross citations over time (Fig. 9). This is especially prevalent since 1995 . However, this is still a preference for referring to papers within the same knowledge domain compared to the number expected when citing randomly. The main increase is caused by cross citations between papers on resilience and vulnerability. The increase in cross citations between papers on adaptation and vulnerability has been occurring for a longer period, perhaps since the late 1980s. Note that in this figure, we exclude citations of papers that are members of two knowledge domains.

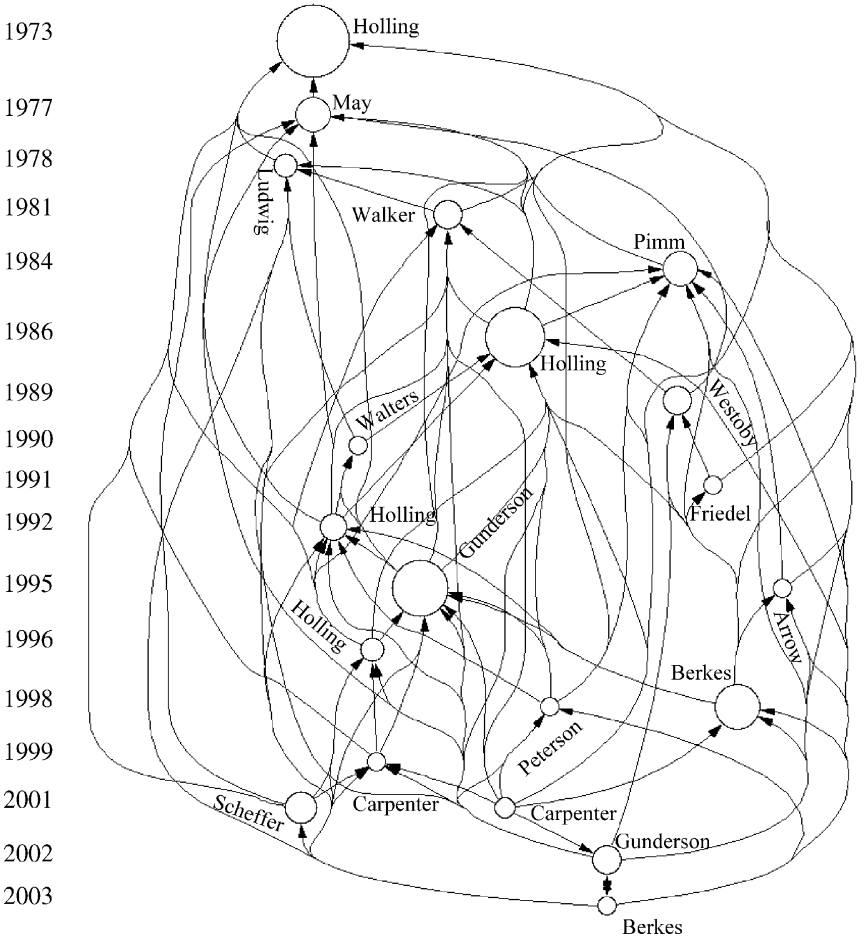

Fig. 5. Paper citation network of the most highly cited papers within the knowledge domain resilience (threshold 20 citations within the dataset). The node size denotes the number of citations, the arrows refer to citations (Carpenter et al., 2001; Holling, 1992; Peterson et al., 1998).

\section{Discussion}

The analysis of the publications related to resilience, vulnerability and adaptation of HDGEC shows that this research area experienced a major and still continuing increase in the number of published papers. It also shows that there are few interlinkages among the three knowledge domains, especially between resilience and vulnerability/ adaptation.

The knowledge domain resilience is dominated by scholars related to the Beijer International Institute of Ecological Economics and RA. This knowledge domain has a number of very productive scholars who frequently cite each other's work. The knowledge domains of vulnerability and adaptation overlap and have similar dynamics. There is no theory or organizing framework that was the seed for the development of these two domains. The research on human-induced climatic change and the changing vulnerabilities and unavoidable necessities for adaptation stimulated the development of the research in the knowledge domains vulnerability and adaptation. This is reflected in the positions of the members of IPCC in the co-authorship network. It is remarkable that major publications on the knowledge domain resilience do not cite the other two knowledge domains vulnerability and adaptation, and the other way round. This observation reflects the historical developments of these domains.

We received a lot of interesting feedback on earlier drafts of this manuscript when it was circulated in academic 


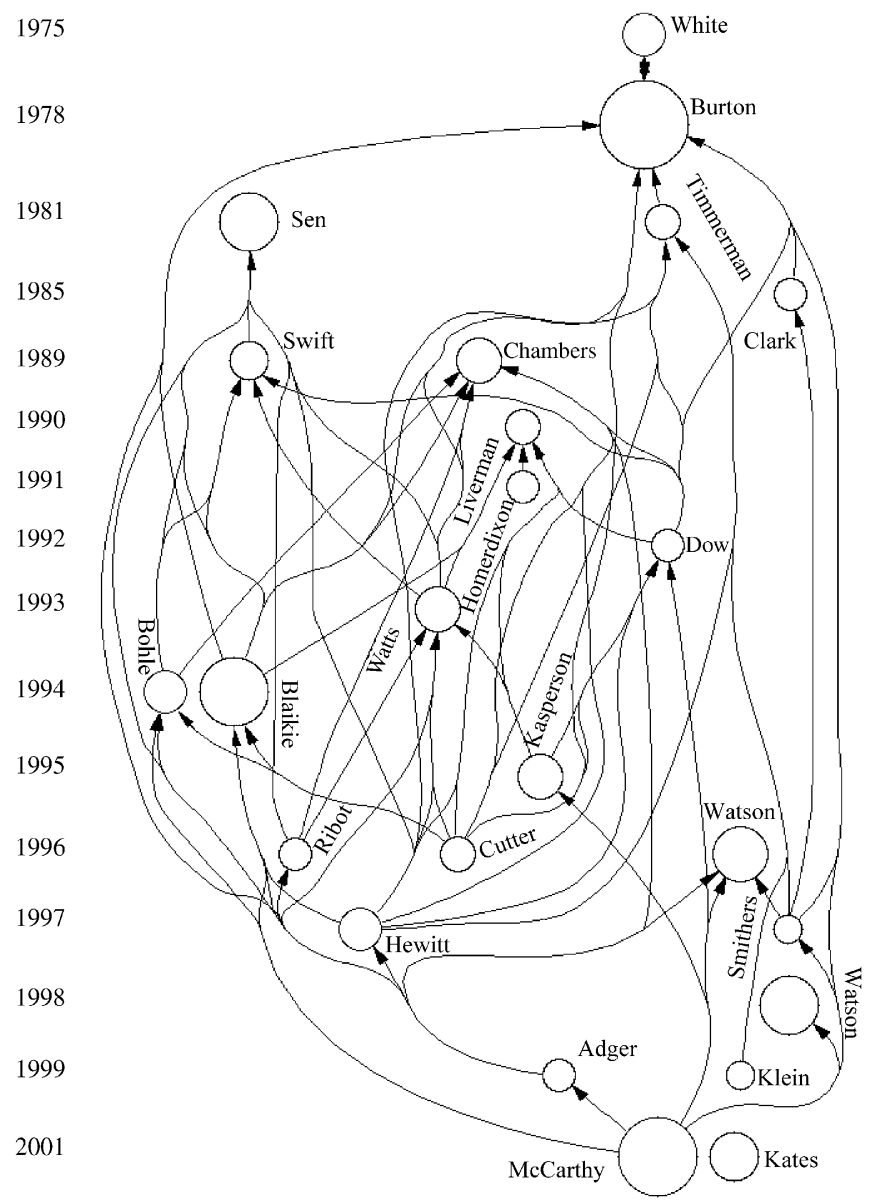

Fig. 6. Paper citation network of the most highly cited papers within the knowledge domain vulnerability (threshold 15 citations within the dataset). The node size denotes the number of citations, the arrows refer to citations.

circles. It is tempting to make statements on the past, present and future of the interdisciplinary research of human dimensions of global change. The nature of this analysis is to provide statistical information of a large dataset, not to make conclusions of individual occurrences. Our analyses do, however, raise certain questions that might be subject for future studies, like "what is the effect of international networks on co-authorship relations and on the diffusion of concepts?" "What are the disciplinary biases and bottlenecks in co-authorship networks in an interdisciplinary field like human dimensions of global environmental change?" These, and other interesting questions, might be useful for future research. From our analysis however, we see a trend of increasing overlap of domains and increasing cross citations. This suggests that an integration of the different knowledge domains into an overarching knowledge domain is looming.

\section{Acknowledgements}

This paper is part of a larger effort to analyze the crosscutting theme of resilience, vulnerability and adaptation for
1967<smiles>[R20][R7]#[R]</smiles>

1980

1981

1992

1994

1996

1997

1998

1999

2000

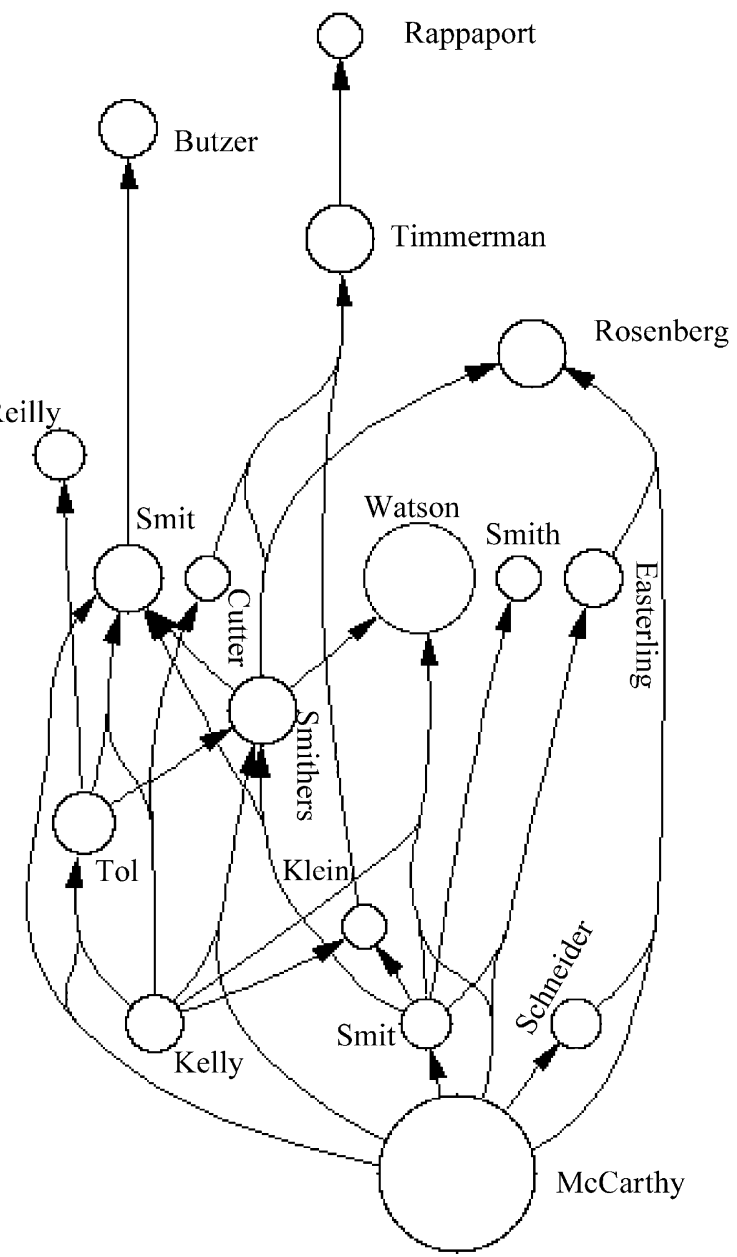

Fig. 7. Paper citation network of the most highly cited papers within the knowledge domain of adaptation (threshold 10 citations with the dataset). The node size denotes the number of citations, the arrows refer to citations (Kelly and Adger, 2000; Reilly et al., 1994; Schneider et al., 2000; Smith and Lenhart, 1996).

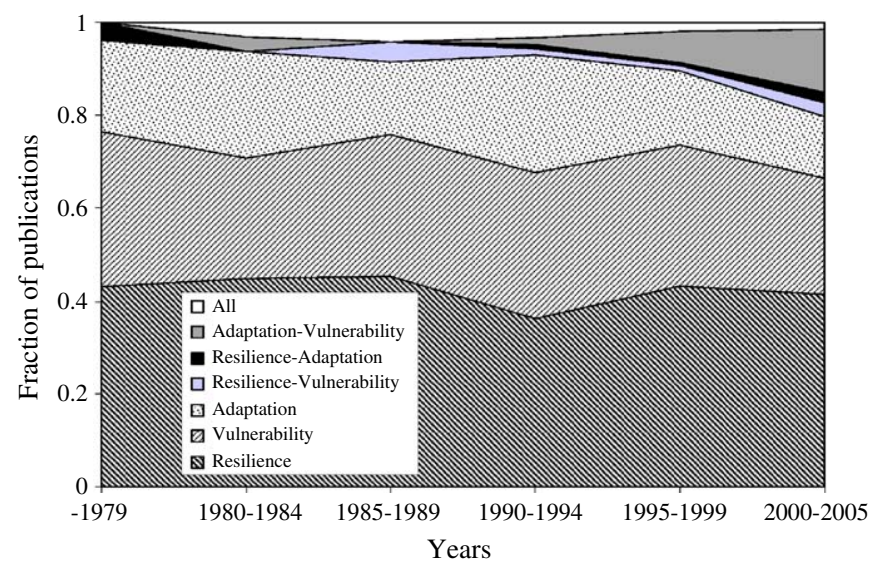

Fig. 8. Relative numbers of publication for the different knowledge domains for six five-year periods. 


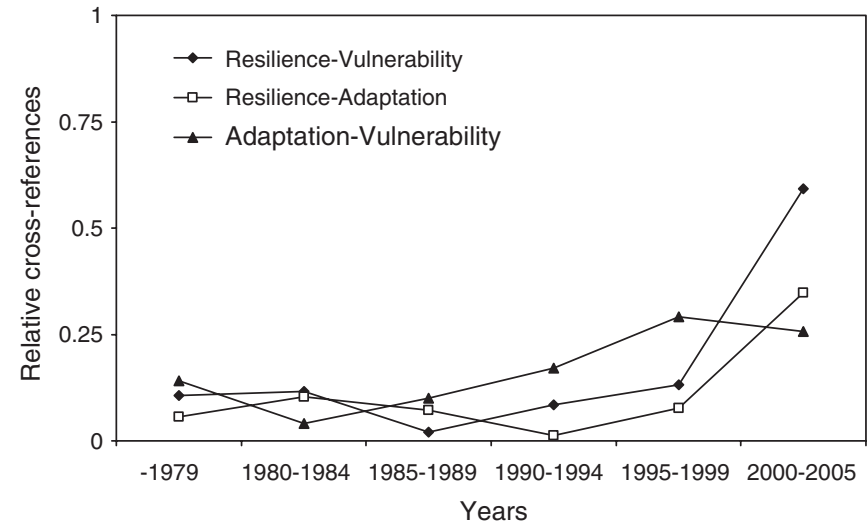

Fig. 9. Citations between distinct knowledge domains as a fraction of the total number of cross citations if citations where made randomly. This is done for six five-year periods.

the study on HDGEC, by a committee chaired by Lin Ostrom. We thank Neil Adger, Marty Anderies, Bill Clark, Carl Folke, Gilberto Gallopin, Roger Kasperson, Emilio Moran, Lin Ostrom, and Oran Young for providing suggestions on relevant literature and providing feedback on earlier versions of this paper. We acknowledge financial support from the IHDP and the National Science Foundation CAREER grant under IIS-0238261 to Katy Börner.

\section{References}

Adger, W.N., 1999. Social vulnerability to climate change and extremes in coastal Vietnam. World Development 27 (2), 249-269.

Adger, W.N., 2000. Social and ecological resilience: are they related? Progress in Human Geography 24 (3), 347-364.

Adger, W.N., 2006. Vulnerability. Global Environmental Change 16 (3).

Arrow, K., Bolin, B., Costanza, R., Dasgupta, P., Folke, C., Holling, C.S., Jansson, B.O., Levin, S., Mäler, K.G., Perrings, C., Pimentel, D., 1995. Economic growth, carrying capacity, and the environment. Science 268 (5210), 520-521.

Batagelj, V., Mrvar, A., 1997. Pajek: Program Package for Large Network Analysis. University of Ljubljana, Slovenia http://vlado.fmf.uni-lj.si/ pub/networks/pajek/.

Berkes, F., Folke, C. (Eds.), 1998. Linking Social and Ecological Systems: Management Practices and Social Mechanisms for Building Resilience. Cambridge University Press, Cambridge, UK.

Berkes, F., Colding, J., Folke, C. (Eds.), 2003. Navigating Socialecological Systems: Building Resilience for Complexity and Change. Cambridge University Press, Cambridge, UK.

Blaikie, P., Brookfield, H., 1987. Land Degradation and Society. Methuen, London.

Blaikie, P., Cannon, T., Davis, I., Wisner, B., 1994. At Risk: Natural Hazards, People's Vulnerability, and Disasters. Routledge, New York, NY.

Bohle, H.-G., Downing, T.E., Watts, M.J., 1994. Climate change and social vulnerability - toward a sociology and geography of food insecurity. Global Environmental Change 4 (1), 37-48.

Börner, K., Chen, C., Boyack, K., 2003. Visualizing knowledge domains. In: Cronin, B. (Ed.), Annual Review of Information Science \& Technology, vol. 37. Information Today, Inc./American Society for Information Science and Technology, Medford, NJ, pp. 179-255.

Boyack, K.W., Bäcker, A., 2004. The growth and memory of science. Sandia National Laboratories report no. SAND2004-2779J.
Burton, I., Kates, R.W., White, G.F., 1978. The Environment as Hazard Oxford University Press, New York, NY.

Butzer, K.W., 1980. Adaptation to global environmental change. Professional Geographer 32 (3), 269-278.

Carpenter, S.R., Ludwig, D., Brock, W.A., 1999. Management of eutrophication for lakes subject to potentially irreversible change. Ecological Applications 9 (3), 751-771.

Carpenter, S.R., Walker, B.H., Anderies, J.M., Abel, N., 2001. From metaphor to measurement: resilience of what to what? Ecosystems 4 (8), 765-781.

Chambers, R., 1989. Vulnerability, coping and policy - introduction. IDS Bulletin-Institute of Development Studies 20 (2), 1-7.

Clark, W.C., 1985. Scales of climate impacts. Climatic Change 7 (1), 5-27.

Costanza R d'Arge, R., de Groot, R.S., Farber, S., Grasso, M., Hannon, B., Limburg, K., Naeem, S., O’Neill, R.V., Paruelo, J., Raskin, R.G., Sutton, P., van den Belt, M., 1997. The value of the world's ecosystem services and natural capital. Nature 387, 253.

Cutter, S.L., 1996. Vulnerability to environmental hazards. Progress in Human Geography 20 (4), 529-539.

Cutter, S.L., 2003. The vulnerability of science and the science of vulnerability. Annals of the Association of American Geographers 93 (1), 1-12.

Dow, K., 1992. Exploring differences in our common future(s)-The meaning of vulnerability to global environmental change. Geoforum 23 (3), 417-436.

Easterling, W.E., 1996. Adapting North American agriculture to climate change in review. Agricultural and Forest Meteorology 80 (1), 1-53.

Folke, C., 2006. Resilience: the emergence of a perspective for socialecological systems analyses. Global Environmental Change 16 (3).

Friedel, M.H., 1991. Range condition assessment and the concept of thresholds - a viewpoint. Journal of Range Management 44 (5), 422-426.

Gallopin, G.C., 2006. Linkages between vulnerability, resilience and adaptive capacity. Global Environmental Change 16 (3).

Garfield, E., 2004. Historiographic mapping of knowledge domains literature. Journal of Information Science 30 (2), 119-145.

Guimerà, R., Uzzi, B., Spiro, J., Amaral, L.A.N., 2005. Team assembly mechanisms determine collaboration network structure and team performance. Science 308, 697-702.

Gunderson, L.H., 2000. Resilience in theory and practice. Annual Review of Ecology and Systematics 31, 425-439.

Gunderson, L.H., Holling, C.S. (Eds.), 2002. Panarchy: Understanding Transformations in Human and Natural Systems. Island Press.

Gunderson, L.H., Holling, C.S., Light, S.S. (Eds.), 1995. Barriers and Bridges to the Renewal of Ecosystems and Institutions. Columbia University Press, New York, NY.

Hardin, G., 1968. The tragedy of the commons. Science 162, 1243-1248.

Hewitt, K., 1997. Regions of Risk: A Geographical Introduction to Disasters. Addison Wesley, Longman, New York, NY.

Holling, C.S., 1973. Resilience and stability of ecological systems. Annual Review of Ecology and Systematics 4, 1-23.

Holling, C.S. (Ed.), 1978. Adaptive Environmental Assessment and Management. Wiley, New York, NY.

Holling, C.S., 1986. The resilience of terrestrial ecosystems: local surprise and global change. In: Clark, W.C., Munn, R.E. (Eds.), Sustainable Development of the Biosphere. Cambridge University Press, Cambridge, UK, pp. 292-317.

Holling, C.S., 1992. Cross-scale morphology, geometry, and dynamics of ecosystems. Ecological Monographs 62 (4), 447-502.

Holling, C.S., 1996. Engineering resilience versus ecological resilience. In: Schulze, P. (Ed.), Engineering Within Ecological Constraints. National Academy, Washington, D.C., pp. 31-44.

Holling, C.S., Meffe, G.K., 1996. Command and control and the pathology of natural resource management. Conservation Biology 10 (2), 328-337.

Ionescu, C., Klein, R.J.T., Hinkel, J., Kumar, K.S.K., Klein, R., 2006. Towards a formal framework of vulnerability to climate change. Environmental Modeling and Assessment, in press. 
Kasperson, J.X., Kasperson, R.E., Turner II, B.L., 1995. Regions at Risk. United Nations Press, New York, NY.

Kates, R.W., Clark, W.C., Corell, R., Hall, J.M., Jaeger, C.C., Lowe, I., McCarthy, J.J., Schellnhuber, H.J., Bolin, B., Dickson, N.M., Faucheux, S., Gallopin, G.C., Grubler, A., Huntley, B., Jager, J., Jodha, N.S., Kasperson, R.E., Mabogunje, A., Matson, P., Mooney, H., 2001. Environment and development-sustainability science. Science 292 (5517), 641-642.

Kelly, P.M., Adger, W.N., 2000. Theory and practice in assessing vulnerability to climate change and facilitating adaptation. Climate Change 47 (4), 325-352.

Klein, R.J.T., Nicholls, R.J., 1999. Assessment of coastal vulnerability to climate change. Ambio 28 (2), 182-187.

Laycock, W.A., 1991. Rangelands-a viewpoint. Journal of Range Management 44 (5), 426-433.

Levin, S.A., 1992. The problem of pattern and scale in ecology. Ecology 73, 1943-1967.

Liverman, D.M., 1990. Vulnerability to global environmental change. In: Kasperson, R.E., Dow, D.G., Kasperson, J.X. (Eds.), Understanding Global Environmental Change: The Contributions of Risk Analysis and Management. Clark University, Worchester, MA.

Ludwig, D., Jones, D.D., Holling, C.S., 1978. Qualitative-analysis of insect outbreak systems - Spruce Budworm and Forest. Journal of Animal Ecology 47 (1), 315-332.

Ludwig, D., Hilborn, R., Walters, C., 1993. Uncertainty, resource exploitation, and conservation: lessons from history. Science 260, $17-36$.

May, R.M., 1977. Thresholds and breakpoints in ecosystems with a multiplicity of stable states. Nature 269, 471-477.

McCarthy, J.J., Canziani, O.F., Leary, N.A., Dokken, D.J., White, K.S. (Eds.), 2001. Climate Change 2001: Impacts, Adaptation, Vulnerability. Cambridge University Press, Cambridge, UK.

Ostrom, E., 1990. Governing the Commons: The Evolution of Institutions for Collective Action. Cambridge University Press, Cambridge, UK.

Peterson, G.D., Allen, C.R., Holling, C.S., 1998. Ecological resilience, biodiversity, and scale. Ecosystems 1 (1), 6-18.

Pimm, S.L., 1984. The complexity and stability of ecosystems. Nature 307 (26), 321-326.

Rappaport, R.A., 1967. Pigs for the Ancestors. Yale University Press, New Haven, CT.

Rappaport, R.A., 1977. Maladaptation in social systems. In: Friedman, J. (Ed.), Evolution of Social Systems. Duckworth, London, UK, pp. 49-71.

Reilly, J.M., Hohmann, N., Kane, S.M., 1994. Climate-change and agricultural trade - who benefits, who loses. Global Environmental Change 4 (10), 24-36.

Ribot, J.C., Magalhães, A.R., Panagides, S.S., 1996. Climate Variability, Climate Change and Social Vulnerability in the Semi-arid Tropics. Cambridge University Press, New York, NY.

Rosenberg, N.J., 1992. Adaptation of agriculture to climate change. Climatic Change 21 (4), 385-405.

Rosenzweig, C., Parry, M.L., 1994. Potential impact of climate change on world food supply. Nature 367, 133-138.
Scheffer, M., Carpenter, S.R., Foley, J.A., Folke, C., Walker, B.H., 2001. Catastrophic shifts in ecosystems. Nature 413, 591-596.

Schneider, S.H., Easterling, W.E., Mearns, L.O., 2000. Adaptation: sensitivity to natural variability, agent assumptions and dynamic climate changes. Climatic Changes 45 (1), 203-221.

Sen, A., 1981. Famines and Poverty. Oxford University Press, London.

Shiffrin, R., Börner, K., 2004. Mapping knowledge domains. Proceedings of the National Academy of Sciences 101 (S1), 5183-5185.

Smit, B., Wandel, J., 2006. Adaptation, adaptive capacity and vulnerability. Global Environmental Change 16 (3).

Smit, B., McNabb, D., Smithers, J., 1996. Agricultural adaptation to climatic variation. Climatic Change 33 (1), 7-29.

Smit, B., Burton, I., Klein, R.J.T., Street, R., 1999. The science of adaptation: a framework for assessment. Mitigation and Adaptation Strategies for Global Change 4 (3-4), 199-213.

Smit, B., Burton, I., Klein, R.J.T., Wandel, J., 2000. An anatomy of adaptation to climate change and variability. Climatic Change 45 (1), 223-251.

Smith, J.B., Lenhart, S.S., 1996. Climate change adaptation policy options. Climate Research 6 (2), 193-201.

Smithers, J., Smit, B., 1997. Human adaptation to climatic variability and change. Global Environmental Change 7 (2), 129-146.

Swift, J., 1989. Why are rural people vulnerable to famine. IDS BulletinInstitute of Development Studies 20 (2), 8-15.

Timmerman, P., 1981. Vulnerability, resilience and the collapse of society. Environmental Monograph 1, Institute for Environmental Studies, Toronto University.

Tol, R.S.J., Fankhauser, S., Smith, J.B., 1998. The scope for adaptation to climate change: what can we learn from the impact literature? Global Environmental Change 8 (2), 109-123.

Vitousek, P.M., Mooney, H.A., Lubchenco, J., Melillo, J.M., 1997. Human domination of earth's ecosystems. Science 277, 494-499.

Walker, B.H., Ludwig, D., Holling, C.S., Peterman, R.M., 1981. Stability of semi-arid savanna grazing systems. Journal of Ecology 69 (2), 473-498.

Walters, C.J., 1986. Adaptive Management of Renewable Resources. MacMillan, New York.

Walters, C.J., Holling, C.S., 1990. Large-scale management experiments and learning by doing. Ecology 71 (6), 2060-2068.

Watson, R.T., Zinyowera, M.C., Moss, R.H. (Eds.), 1996. Climate Change 1995: Impacts, Adaptations, and Mitigation of Climate Change. Cambridge University Press, Cambridge, UK.

Watson, R.T., Zinyowera, M.C., Moss, R.H. (Eds.), 1998. The Regional Impacts of Climate Change: An Assessment of Vulnerability. Cambridge University Press, Cambridge, UK.

Watts, M.J., Bohle, H.G., 1993. The space of vulnerability-the causalstructure of hunger and famine. Progress in Human Geography 17 (1), 43-67.

Westoby, M., Walker, B.H., Noymeir, I., 1989. Opportunistic management for rangelands not at equilibrium. Journal of Range Management 42 (4), 266-274.

White, G.F., Haas, J.E., 1975. Assessment of Research on Natural Hazards. MIT Press, Cambridge, MA. 